\title{
Structures, processes and achievements of the nationalprogram of congenital hypothyroidism screening in the Islamic Republic of Iran
}

\author{
Yarahmadi $\mathrm{S}^{1}$, Aghang $\mathrm{N}^{2}$, Nikkhoo $\mathrm{B}^{3}$, Rahmani $\mathrm{K}^{4}$ \\ 1. Assistant Professor of Endocrinology, Department of Endocrinology and Metabolism, Ministry of Health, Tehran, Iran. \\ ORCID ID: 0000-0002-6020-7789 \\ 2. NCD Expert, Department of Endocrinology and Metabolism, Ministry of Health, Tehran, Iran. \\ 3. Associate Professor of Pathology, Department of Pathology, School of Medicine, Kurdistan University of Medical \\ Sciences, Sanandaj, Iran. \\ 4. Assistant Professor of Epidemiology, Liver and Digestive Research Center, Research Institute for Health Development, \\ Kurdistan University of Medical Sciences, Sanandaj, Iran (Corresponding Author), Tel: +988733291100, Email: \\ khaledrahmani111@muk.ac.ir, ORCID ID: 0000-0002-0860-8040
}

\begin{abstract}
Background and Aim: Screening of neonates for early detection and timely treatment of congenital hypothyroidism $(\mathrm{CH})$ is one of the most important public health programs in the world. The purpose of this study was to review the structures, processes and achievements of the $\mathrm{CH}$ Screening program in Iran.

Materials and Methods: Data were obtained from the surveillance program of the noncommunicable diseases office, review of records, documents, books, published articles and also interviews with process owners and experts of $\mathrm{CH}$ screening program in Iran in 2019.

Results: TSH measurements on the $3^{\text {rd }}$ to $5^{\text {th }}$ days after birth, supplementary and confirmatory testsfor children with $\mathrm{TSH} \geq 5 \mathrm{mu} / \mathrm{L}$,timely treatment of hypothyroid children using levothyroxine tablets and assessment of the program by follow-up and continuous monitoring were the most important parts of the national neonatal screening program for congenital hypothyroidism in Iran.

Conclusion: The present study provides an overview of the principles and implementation of the $\mathrm{CH}$ screening program in Iran, and can be used as an educational and research source for policymakers, researchers, and health providers who work in the field of neonatal metabolic disorders.
\end{abstract}

Keywords: Congenital hypothyroidism, Neonates screening, Iran

Accepted :June 30, $2019 \quad$ Received: July 21, 2019

How to cite the article: Yarahmadi S, Aghang N, Nikkhoo B, Rahmani K. Structures, processes and achievements of the nationalprogram of congenital hypothyroidism screening in the Islamic Republic of Iran. SJKU 2019;24(4):10-21.

Copyright (C) 2019 the Author (s). Published by Kurdistan University of Medical Sciences. This is an open access article distributed under the terms of the Creative Commons Attribution-Non Commercial License 4.0 (CCBYNC), where it is permissible to download, share, remix, transform, and buildup the work provided it is properly cited. The work cannot be used commercially without permission from the journal. 


\title{
ساختار، فر آيندهاى اجرايى و دستاوردهاى برنامه كشورى غربالكرى بيمارى كمكارى تيروئيد نوزادان در جمهورى اسلامى ايران
}

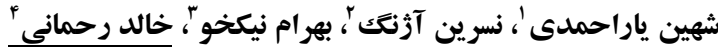

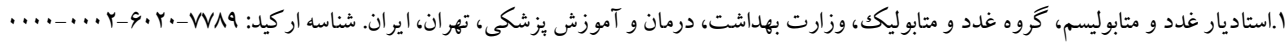

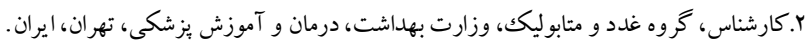

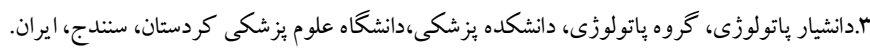

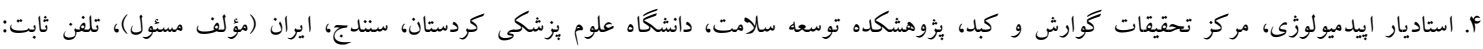

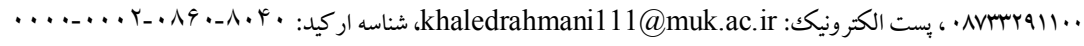

جكيله

زمينه و هدف: غربالكرى، شناسايى بههنكام و درمان زودرس و مناسبيمارى كم كاريتيروئيد نوزادان يكى از مهم ترين برنامههـاى

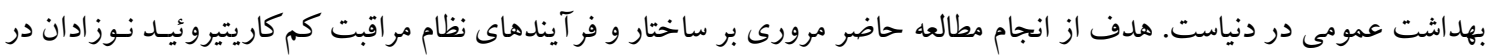
ايران است.

روش بررسى: دادههاى اين مطالعه از نظام مراقبت دفتر بيمارىهايغيرواگير، بررسى اسناد، مدارك،، كتاب ها و مقالات منتشر شده

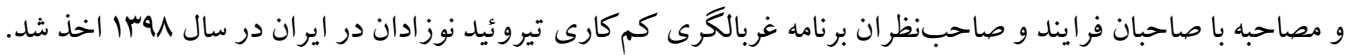

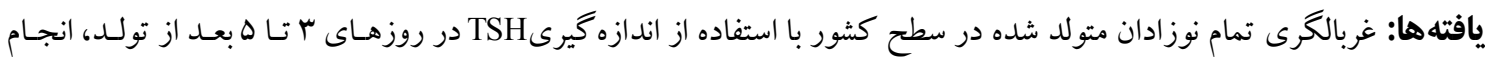

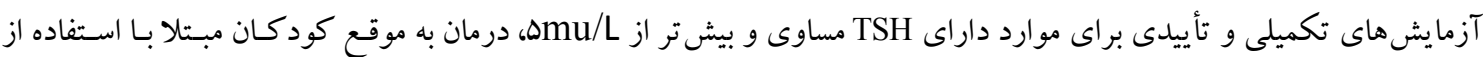

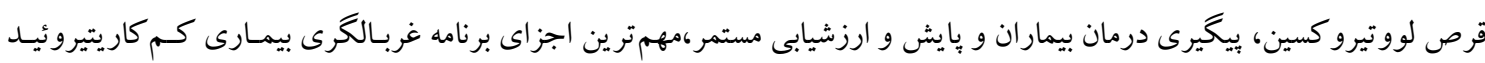

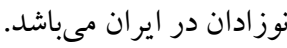

نتيجه كيرى:مطالعه حاضر جِكيدهاى از اصول، كليات و نحوه اجراى برنامه كشورى غربالكرى بيمارى كم كاريتيروئيد نوز ادان در

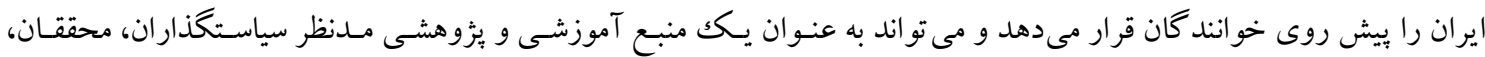

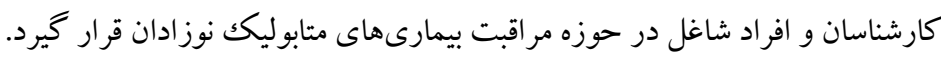
كلمات كليدى: كم كارى مادرزادى تيروئيد، غربالكرى نوزادان، ايران

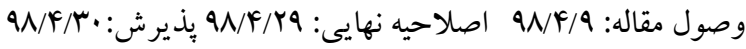


بتوانـــ ايـن بيمـارى را در روزهـاى آغـازين زنــــى نـوزاد

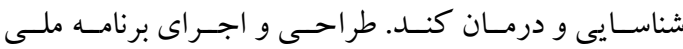

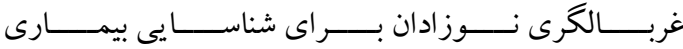
كم كاريتيروئيدنوزادان يكى از برنامهاى مهم ادغام شده در نظام مراقبتهاى بهـداشتى ايران است. از آنجاكـه ايـن برنامـهـ در سطح ملى و با يـك سـاختار گسـترده در ايـران در حسال

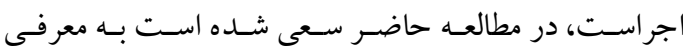
ساختارها، فر آيندهاى اجرايى و دستاوردهاى اجراى آن در كشور يرداخته شود.

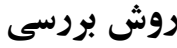
نوع مطالعه

مطالعه حاضر از نوع مطالعات مرورى است كـه بـه معرفى و

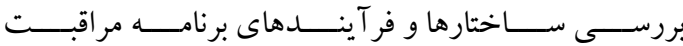
كم كاريمادرزاديتيروئيد يا به عبارت ديخر كم كارى تيروئيد نوزادان در ايران برداخته است.

مر احل مطالعه

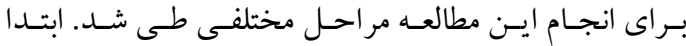

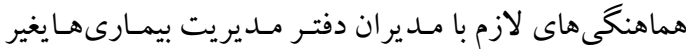
واكير و همجنين مديران و كارشناسان اداره بيمارىهاى غدد و متابوليكك مر كز مديريت بيمـارىهـايغير واكير كشـور بـهـ عمل آمد. سيس تمام دستور العمل ها و مستندات انتشار يافتهـ درزمينه مراقبت كم كـارى تيروئيـد نـوزادان در ايـران مـورد بررسى قرار گرفت. در كام بعـدى بـا مر اجعهـ بـه واحـدهاى

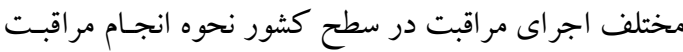

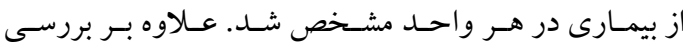
مستندات و كايدلاينها، از نظر ات مدير ان و دست اندر كاران نظام مر اقبت كم كارى مادرزادى تيروئيد هم استفاده شد. هدف مطالعه از آنجا كه هدف مطالعه حاضر معرفى سـاختار، فر آيندهاى مطاى

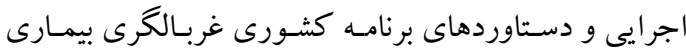
كم كاريتيروئيدنوزادان در ايران بود، بـراى انسجام در ارائهـ
مقدمه

بيمارى كم كاريتيروئيد نوزادان به وضعيتى اطـلاق مسى شـود كه غلظت هورمونهاى تيروئيدى در جريان خون نوزاد كـم باشد(1). اين بيمارى يكى از بيمارىهاى مهـم دوره نـوزادى

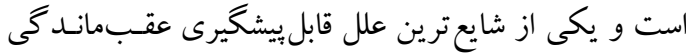
ذهنى محسوب مى شود. علاوه بر اين، در نوزادانى كه مبـلالا

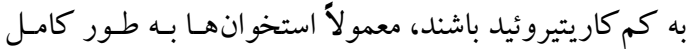

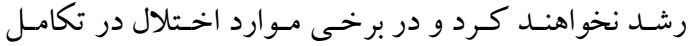

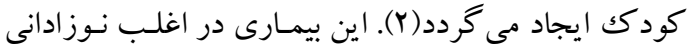
كه به آن مبتلا هستـند، هـيج كونـه علائسم مشخصى ايجـاد نمى كند و ممكن است وجود بيمارى در نوزاد حتى تـا جنـــ

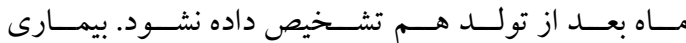

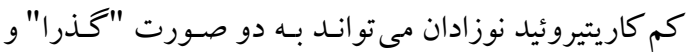
"دائمى" باشد (r). در ارتباط با بروز واقعى اين بيمـارى در نـوزادان، تـا قبـل از

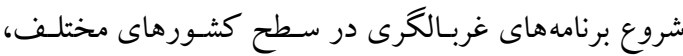

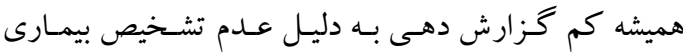

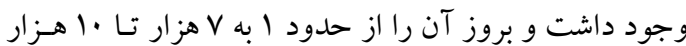
تولد زنده گزاش مى كردند(F). به دنبـال اجراى برنامـهــاى غربالخرى در كشورهاى بيشرفته دنيا، تخمسين دقيـقترى از

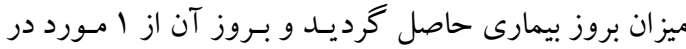

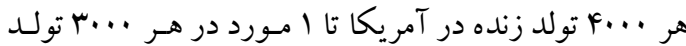

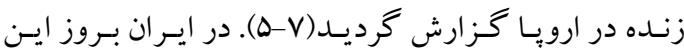
بيمارى نسبت به كشورهاى بيشر فته صنعتى بالاتر است و در

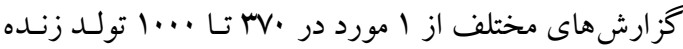

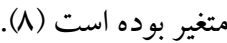
بر اساس شواهد علمى موجود، اخر جه ابتلا بـه ايـن بيمـارى با عوارض مختلفى ازجملهعقبماندى همـر اه اسـت امـادر

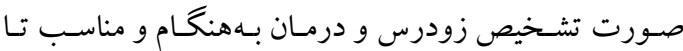
حدود زيادى مى توان نسبت به بيشخيرى از بروز عوارض آن

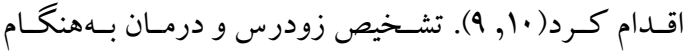
نيازمند طر احى يكك ساختار مر اقبتى منسـمب مسى باشـد كـه 
شهرى و روستايى) بـا بـيشبينيزيرسـاختهـاى لازم و كليـه

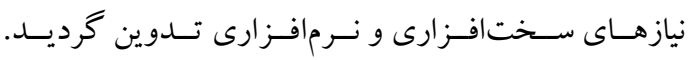

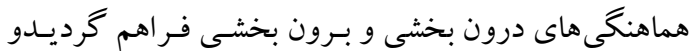

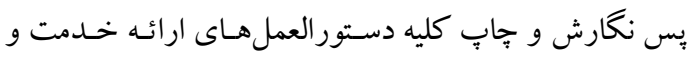

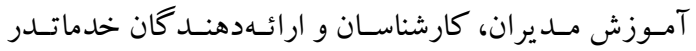

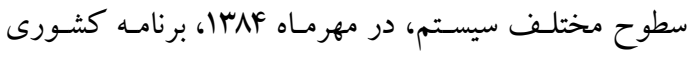

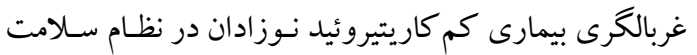
كشور ادغام شد (11).

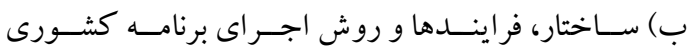
غربالكرى بيماريكم كاريتيروئيد نوز ادان در ايران

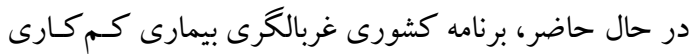

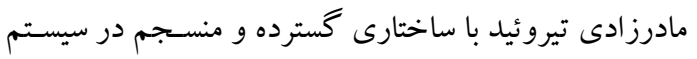

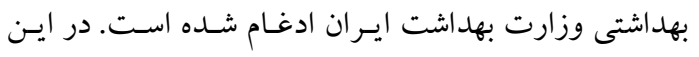
برنامه ادغام يافته، اجززاى زيـر در سطوح مختلـف سيستم

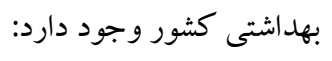
اداره بيمارىهـاى غـدد و متابوليكك:ايسن اداره زيرمجموعـهـ دفتر مديريت بيمارىهايغير واگير است. در حال حاضر ايسن

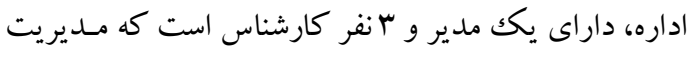

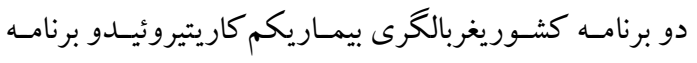
بيشخيرى و كنترل بيمارى ديابت را برعهده دارد.

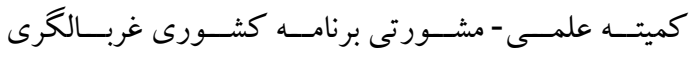
كم كاريتيروئيد نوزادان: وظايف اين كميته، مشاوره در اتخاذ

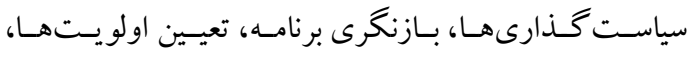

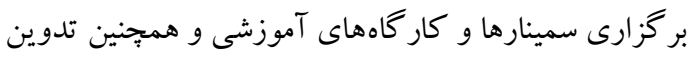
بروتكل هاى نحوه مراقبت و درمان بيماران است.

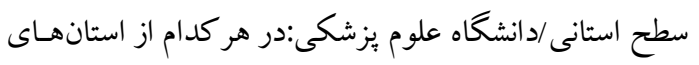

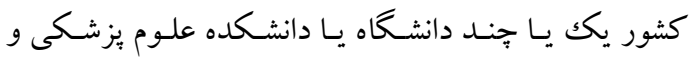

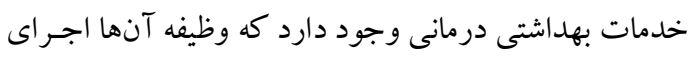

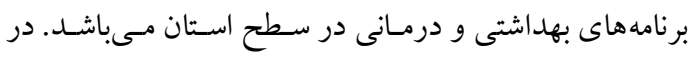

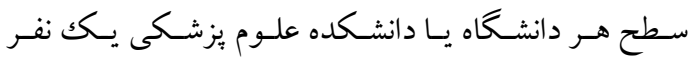

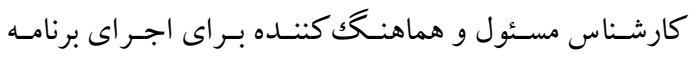

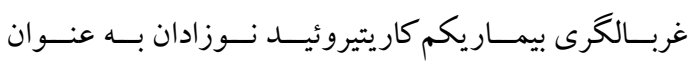

مقاله، يافتهــاى مطالعهـ در جِنـدين بخـش شـامل تاريخجهـه استقرار برنامه غربالكرى نوزادان در ايران، ساختار فعلى نظام مر اقبت اين بيمارى، شرح مختصرى ازاجر اي برنامه در حسال حاضر و تغييرات نظـام مراقبـت ايسن بيمـارى در طول زمـان

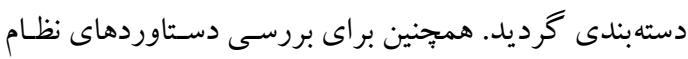

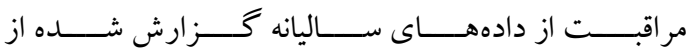
دانشگاه /دانشكدهها يعلوم بزشكى مجرى برنامه در كشـور بـهـ

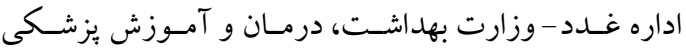

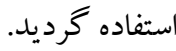

يافته ها

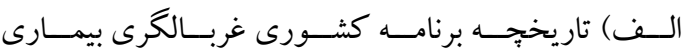

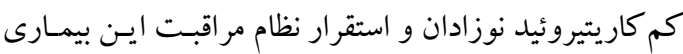

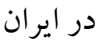

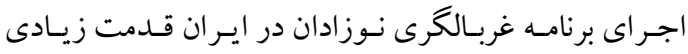
ندارد. در دهه . وعا هجرى شمسى و قبـل از اجـراى برنامـهـ

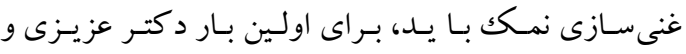

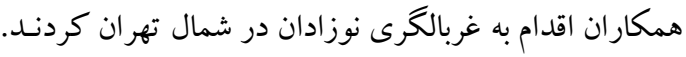

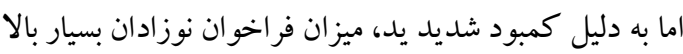

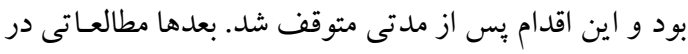
بعضى استانها از جمله فارس و اصفهان انجام شد اما تا دهـه

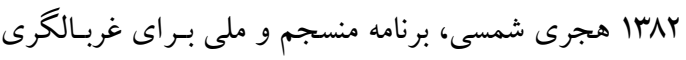

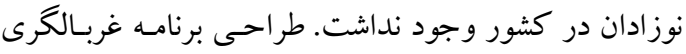

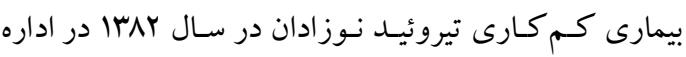

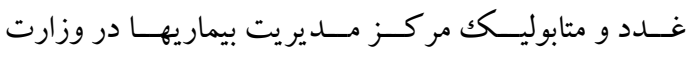
بهداشت، درمان و آموزش بزشكى توسط كارشناسـان ايسن اداره با همكارى كميتههاى تخصصى علمى و اجرايى انجام

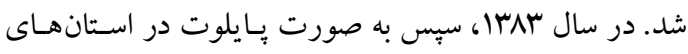

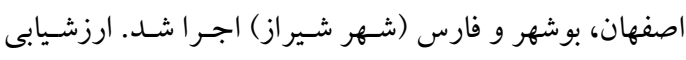

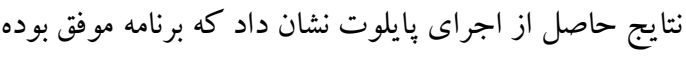

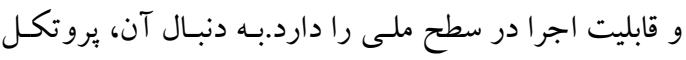
استانداردها و الزامات ادغام برنامه در سطح ملى (در مابلى منساطق

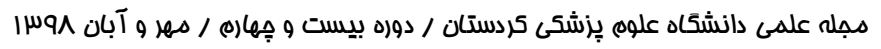


هورمونها يتيروئيد جهـت شناسـايى مـوارد كــم كاريتيروئيسد

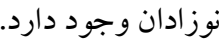

مراكز خدمات جامع سـلامت شـهرى و روسـتايى:در منـاطق مختلف شهرى و روستاهاى بزرگك يكك مركز جامع سلامت وجود دارد. در ايسن مراكـز يزشـك، كارشـناس يـا كـاردان مبارزه بيماريها و ساير برسنل بهداشتى ارائسدهنـده خــدمات مستقر بوده و فعاليتهاى سـطح اول مر اقبـت بيمـارى شـامل آموزش جمعيت، بيگيرى انجام غربالكرى و بيگيرى درمـان كود كان مبتلا را بر عهده دارند. خانه هـاى بهداشـت:در خانـهــاى بهداشـت كـه در روسـتاها

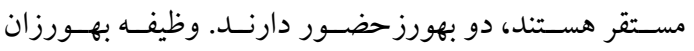
آمــوزش و اطـلاعرســانيدرزمينه بيمـارى و اهميـت انجــام غربـالكرى بـه زنـان بـاردار و بيخيـرى انجـام آزمـايشهــاى غربالكرى و تشخيصى و همجينين بيخيـرى درمـان كودكـان مبتلا است. دســتور العمل هــا: برنامــهـ كشــورى غربــالخرى بيمـــارى كم كاريتيروئيد نوزادان در ايـران داراى جهـار دسـتور العمل اصلى آموزشى - اجرايى به شرح زير مىباشد:

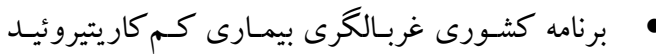
نوزادان (دستور العمل ويزٔه بزشك) • برنامه كشـورى غربـالخرى بيمـارى كـم كاريتيروئيـد نوزادان (دستور العمل ويثه كارشناس) • برنامه كشـورى غربـالكرى بيمـارى كـم كاريتيروئيــ

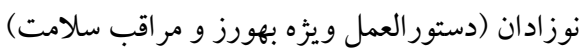
كتابجه آموزشى ويثه و الدين نوزادان بيمار نحوه اجراى برنامسه غربـالكرى نـوزادان در ايسر ان: در برنامسه كشورى غربالخرى بيمارى كم كاريتيروئيد نوزادان، در زمان باردارى آموزشهاى لازم درزمينه اهميت غربالكرى نوز ادان به مادر داده مى شود. به علاوه، در زمـان زايمـان، نيـز، يـك بروشور حـاوى اطلاعـاتى در ارتبـاط بـا اهميـت غربـالكرى نوزادان و عوارض ناشـى از عـدم انجـام آن و آدرس مراكـز نمونه گيرى نوزادان به مادر داده مى شود.
زير مجموعـه مـديريت بيشـحيرى و مبـارزه بـا بيمـارىهـاى معاونت بهداشتى دانشـاه/ دانشـكده علسوم يزشـكى وظيفـه مديريت اجرايى ايسن برنامسه در جمعيـت تحـت يوشـش آن دانشگاه را بر عهده دارند.

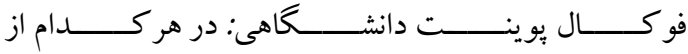

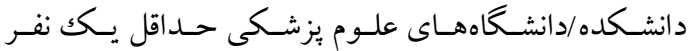
متخصص غدد يا فوق تخصص غدد اطفال و يـا نـوزادان بـهـ

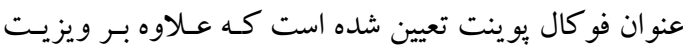
كود كان مبـتلا، در مـوارد نيـاز مشـاوره لازم بـه متخصصـان كود كان و نوزادان و افرادى كه دركير درمان كود كان مبتلا

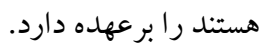
ســطح شهرســان: در حـــوزه تحــت يوشـش هركــــام از

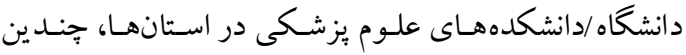
شهرسـتان وجــود دارد و در هركــام از ايسـن شهرسـتانهــا واحدى به نام شبكه بهداشت و درمان شهرستان وجـود دارد كه دو بخـش بهراشـت و درمـان شهرسـتان را بـه ترتيـب در قالب مر كز بهداشت شهرسـتان و بيمارسـتان/بيمارسـتانهـاى شهرستان زير نظر دارد. در سـاختار هـر مركز بهداشـت در سـطح شهرسـتان هـم يـكك نفــ بـهـ عنـوان كارشـناس برنامـهـ بيمارى كم كاريتيروئيد نوزادان وجـود دارد و زيسر مجموعـه واحسل بيشـكيرى و مبـارزه بـا بيمـارىهـاى مركـز بهداشـت مسئوليت اجراى برنامه كشورى غربـالكرى بيمـاريكم كـارى تيروئيد نوزادان در سطح شهرستان را بر عهده دارد. آزما يشگاه غربالخرى نوزادان: در هر استان يك و در كـلان شهر تهران ب آزمايشگاه غربالكرى نـوزادان وجـود دارد كـه يس از دريافت نمونه هاى غربالخرى (كاغـذ كَاترى حـاوى

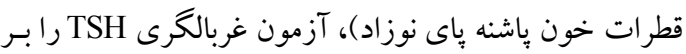

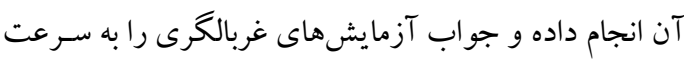
در اختيار مراكز نمونه گيرى از يُشنه يُا مى گذارد.

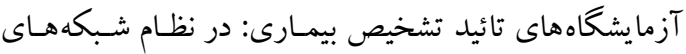
بهداشتى و درمانى كشـور، در همسه شهرسـتانهـا و حتى در

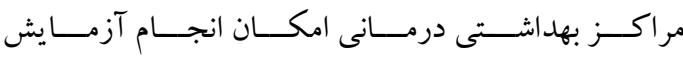




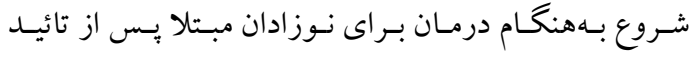
تشخيص جزو فر ايندهاى اصلى برنامه هستند.

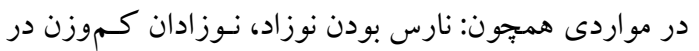

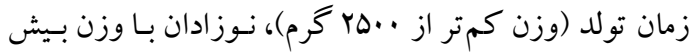

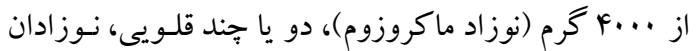
بسترى يا بـا سـابقه بسترى در بيمارستان، نـوزادان بـا سـابقه دريافت و يا تعـويض خـون، نـوزادانى كـه طبق اظهار نظر TSH TSمايشگاه نمونه نامناسب داشتهاند، نوزادانى كه مقدار اوليه آنها بين/9/9mu/L - ه بوده است و همجنين نوز ادانى كـه برخى داروهـاى خـاص از جمله دويـامين و تر كيبـات التهات

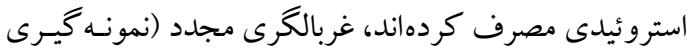
مجدد از ياشنه) در هفته دوم يس از تولـد توصسيه مسى شـود.

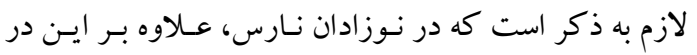

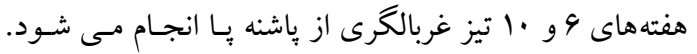

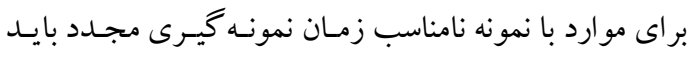

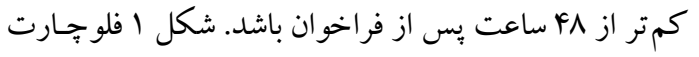
نحوه غربالكرى نوز ادان را نشان مى دهد.

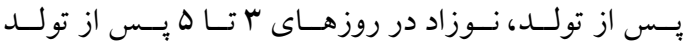
نمونه كيرى از باشنه بِ بر روى كاغذ كاترى S\&S

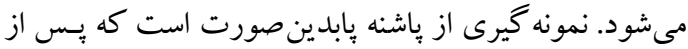
ثبت مشخصات نوزاد و والدين آن از جمله اطلاعات تماس تلفنس، مشخصـات دمو گرافيكك و بـالينى كودك، شـماره كاغذ فيلتر به صورت خو انا و دقيق روى فرم شماره ا، محل

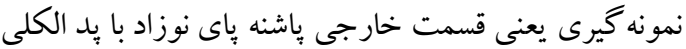

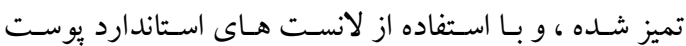

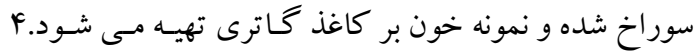

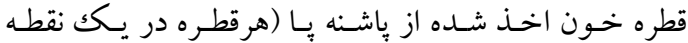
مشخص) بر روى كاغذ فيلتر قرار داده مى شـودنمونسهـا در

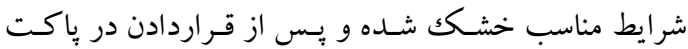

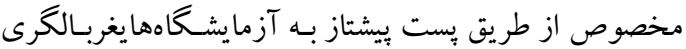

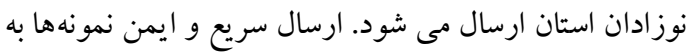
آزمايشگاه غربالكرى نوزادان، انجـام سـريع و دقيـق آزمـون

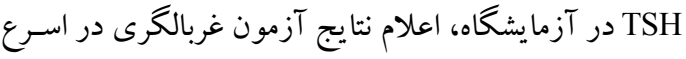

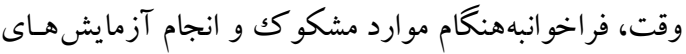

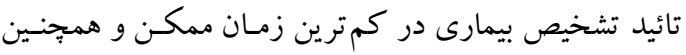

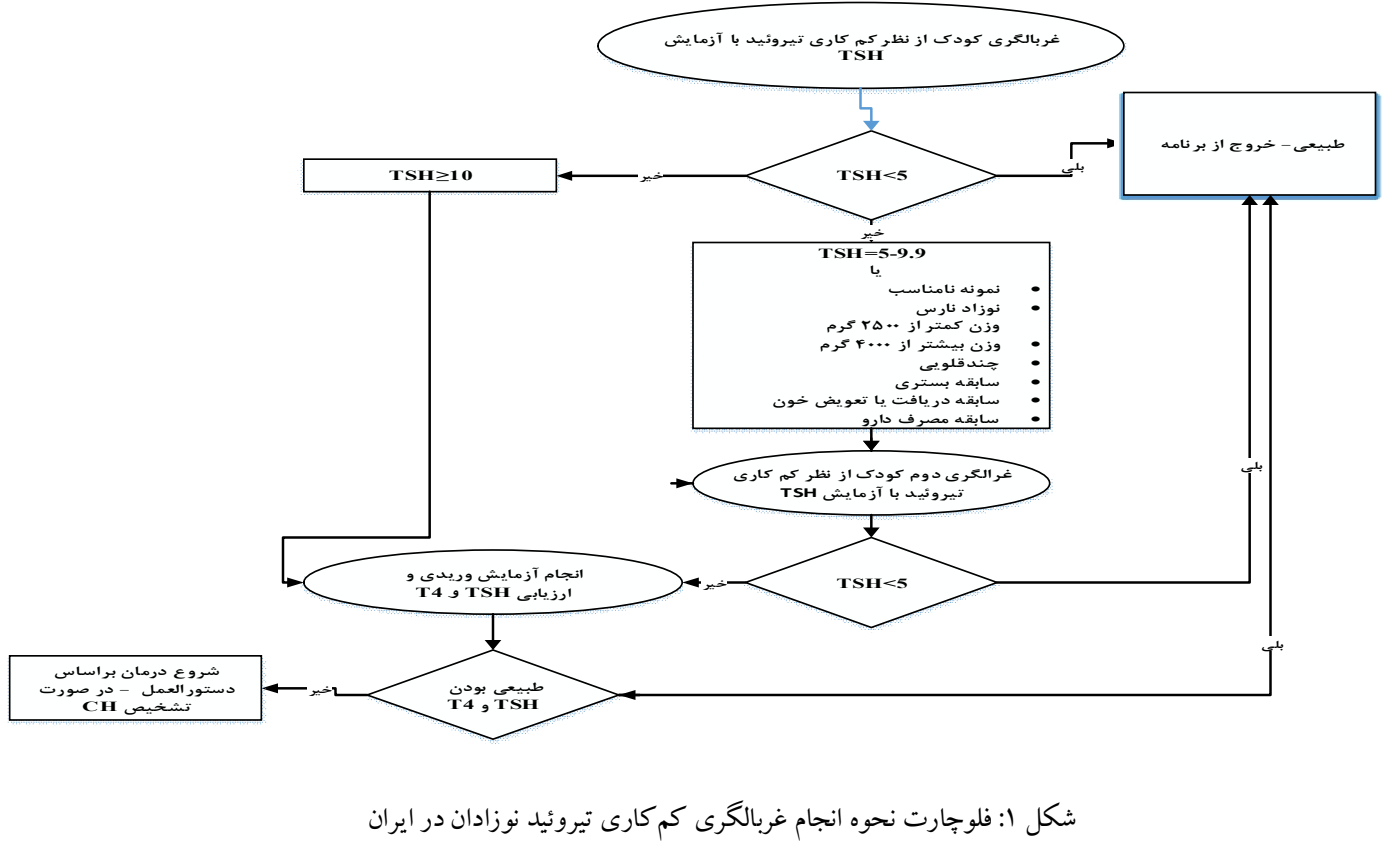

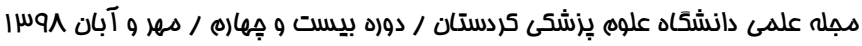




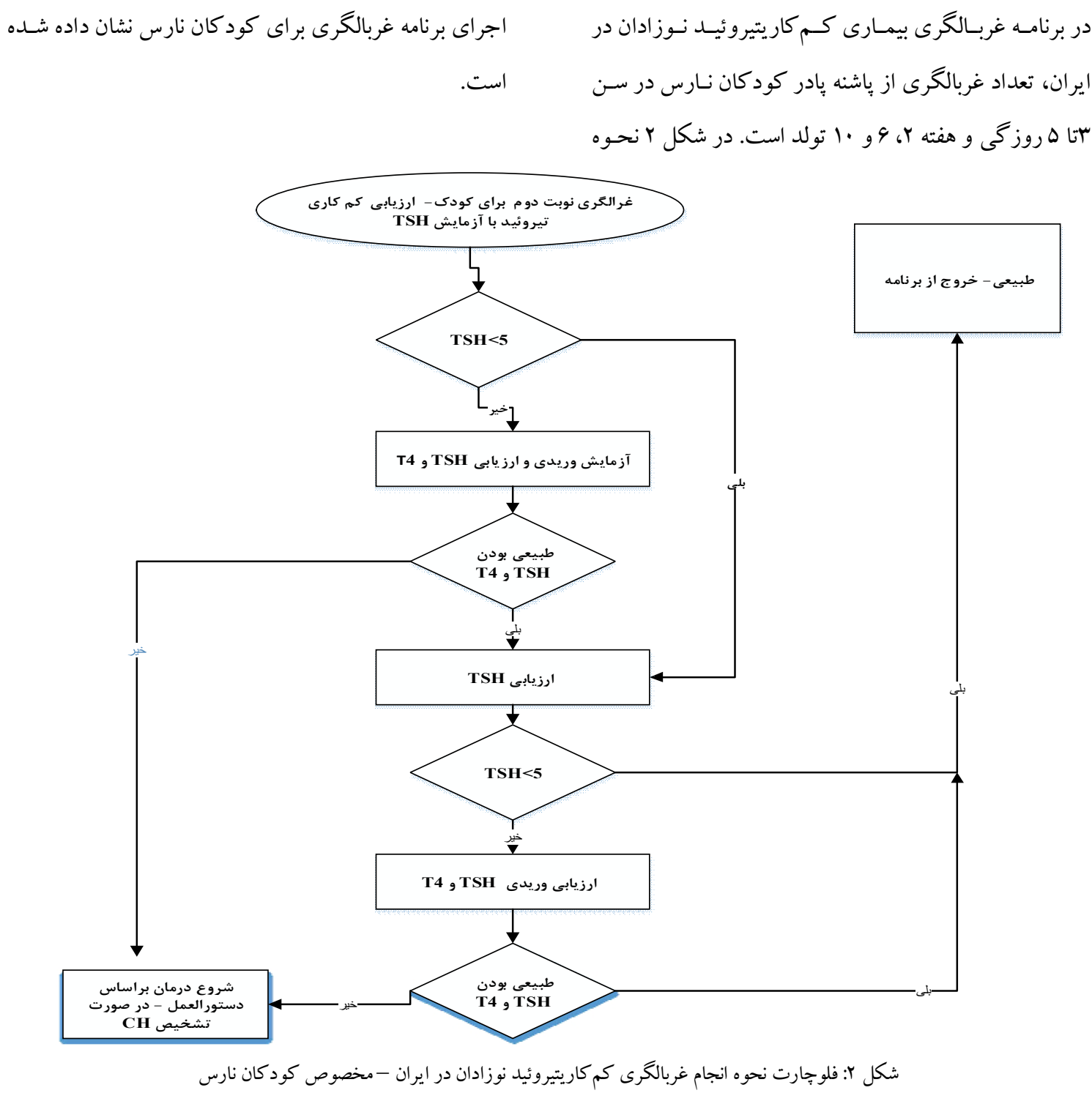


r) كاهش دوز قرص لو تيرو كسين بـه نصف دوز مصـرفى و

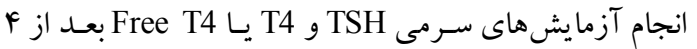
هفته. در صورت غيرطبيعى بـودن آزمايش هـاى هورمسونى،

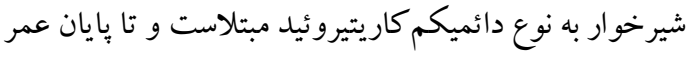

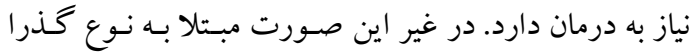

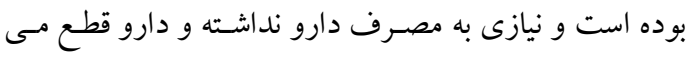
اقدامات بِ از قطع دارو در شيرخو ارانى كه با تشـخيص بيمـارى كـم كـارى تيروئيسد

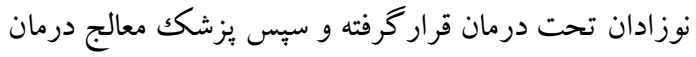

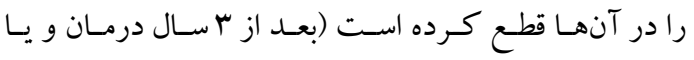

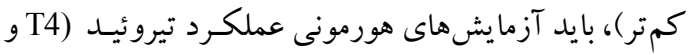

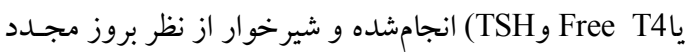

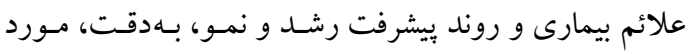

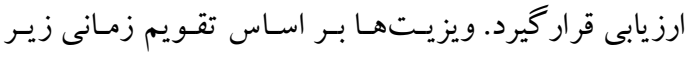

$$
\text { توصيه مىشود: }
$$
F Pفته بعد از قطع دارو

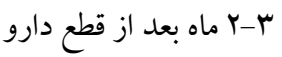
هرسال بعد از قطع دارو جأا هـ سالخى (در مبتلايان به سندرم

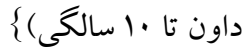
دستور العمل غربالكرى در نوز ادان بسترى در بيمارستان در ارتباط با نوزادان بسترى در بيمارستان دقـت زيـادى بايســ اعمال شود زيرا احتمال فر اموش شدن غربالكرى و همجنسين

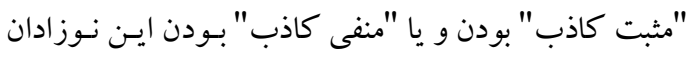

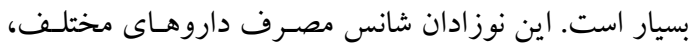

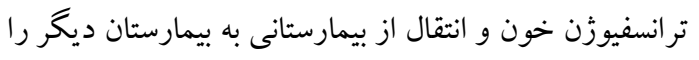
دارند كه مى تو انند مسئله ساز باشند.

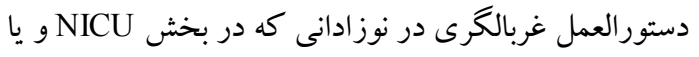
ديخر بخشهاى بيمارستان بسترى هستند بهشرح زير است:

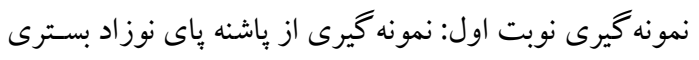

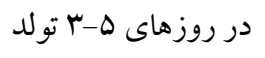

نحـــوه درمــان و مراقبــت نــوزادان مبــتلا بــهـ بيمـارى كم كاريتيروئيدـ نـوزادان: درمـان انتخابى در ايـن بيمـارى، استفاده از قرص لو تيروكسين اسـت. اهــاف اصلى درمـان

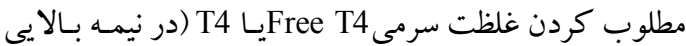
محدوده نرمال آزمايش) و TSH(در نيمـه بـايينى محسدوده نرمال آزمايش)،به ترتيب در مدت ب و و F هفته است.

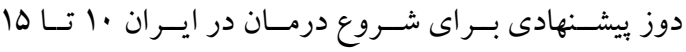

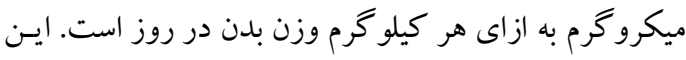
دوز بعدها توسط يُشك بر اساس غلظت سـرمى TSH و TSH

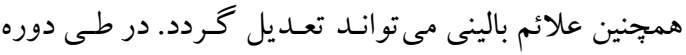

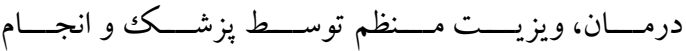

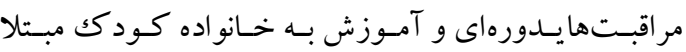
ضرورى است. طبق دستور العمل كشورى، ويزيـت مبتلايـان به بيمارى مىبايست به صورت زير انجام شود:

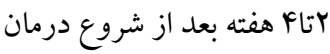

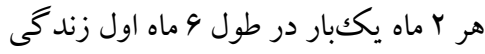

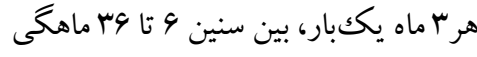

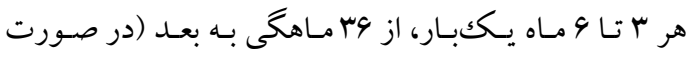

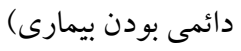
براى بررسى بيمارى در كود كان ازنظر گذذرا يا دائمى بـودن،

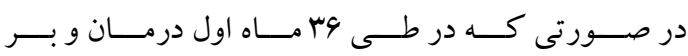

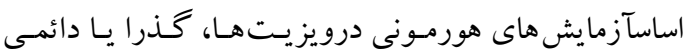
بودن بيمارى مشخص نشود،براى تفكيك كذرا و و دائميبودن

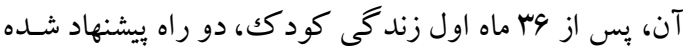
1)قطع مصـرف قرص لو تيروكسين و انجـام آزمايشهـاى

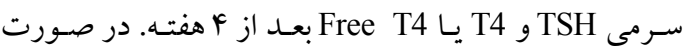

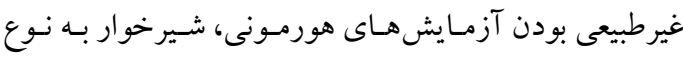
دائميكم كاريتيروئيد مبتلاست و تا بايان عمر نيساز بـه درمـان

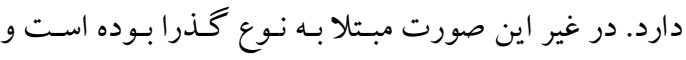

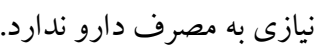


در صورتى كه سن نوزاد كم تر از بروز (rV سـاعت) بـوده و نوز اد نياز به انتقال به بيمارستان ديخر دارد:

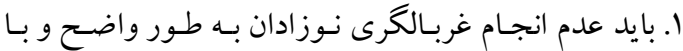
خود كار قرمز در يرونده بسترى نوزاد قيد شود (نمونسه گيـرى

از بِاشنه پِا انجام نشده است).

r. اهميت انجام غربالكرى نوزادان به والدين گُشزد شـده و از آنان خواسته شود كه در بيمارستان مقصد انجام غربالخرى از ياشنه پا (در روز ه-r تولد) را از مسئولين بخش بخواهند. در صورتى كه نوزاد در سن V-Y تولد باشد:

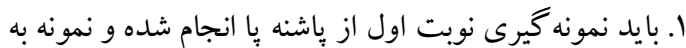
آزمايشگاه غربالخرى ارسال شود. r. انجام غربالكرى نوزادان به طور واضح و با خود كار قرمـز در برونده بسترى نوزاد قيد شود (نمونـهـيــى نوبـت اول از

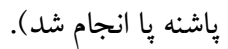
م. اهميت انجام غربالخرى نوبت دوم به والدين گُشزد شـده

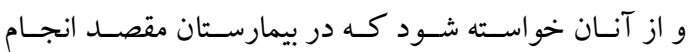

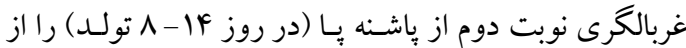
مسئولين بخش بخو اهند. در صورتى كه نوزاد در سن بيش از V روز بوده (تـادو مـاه و ه ب روز از تولد) و به هر علتى غربالكرى نشده باشد: ا. بايد قبل از انتقال از بيمارستان، نمونه گيرى از يّاشنه يـا بـر كاغذ فيلتر انجام گيرد (حتى اگر آزمايشهاى تيروئيـدى از

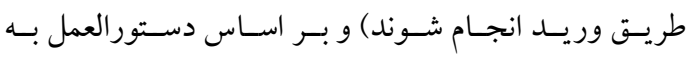
آزما يشگاه ارسال كردد. r. انجام غربالكرى نوز ادان بهطور واضح و با خودكـار قرمـز در برونده بسترى نوزاد قيد شود. ج) تغييرات نظام مراقبت كم كارى تيروئيد نوزادانسـر ايـران در طول زمان برنامه مراقبت كم كاريتيروئيد نوزادان كم ترين تغييرات رادر

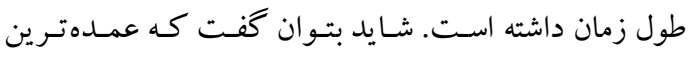
تغييرات اين برنامه، انجام آزمايش غربالخرى مجدد از يّاشـنه

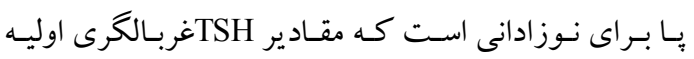

نمونه گيرى نوبت دوم: نمونه گيرى از ياشنه ياى نوزاد بسترى

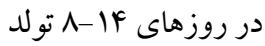
در نوزادانى كه بههر علتى در بيمارستانبسترى شدهاند بايد: () در كليه نوزادان بسترى شده، حتى اخر بهصورت وريـدى آزمايشهاى تيروئيد جّك شده باشند، بايد نمونه كاغذ فيلتر (بـر اسـاس دسـتور العمل كشـورى) انجـام شـده و اطلاعـات مربوط به نوزاد در فايـل اطلاعـاتى برنامـه ثبـت گ حردد.مخـر اين كه والدين بر گه اخذ نمونه از ياشنه ياى نـوزاد در مراكـز نمونه كيرى را ارائه دهند و يا با كسـب اطـلاع از آزمايشـكاه غربالخرى از انجام غربالخرى اطمينان حاصل شود. r) قبل از ترخيص نوزاد از بيمارستان، نمونه گيرى از ياشنه پيا انجام شده و نمونه اخذ شـده در اسـرع وقـت بـه آزمايشـكاه

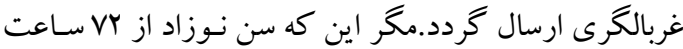
كم تر باشد، كه درايسن صـورت بايسـ والـدين كـاملاً مجـاب شوند كه در روز ه-ب تولـد بـه مراكـز نمونـه كيـرى مراجعـهـ نموده و نوزادشان راغربالكرى كنند. ץ) در صورتى كه نوزاد تا هفته دوم تولد، هنوز در بيمارستان بسترى باشد بايد نمونه كيرى نوبت دوم نيز، از باشنه يا انجـام شــده و نمونــه اخـذ شــده در اسـرع وقـت بـهـ آزمايشـكاه غربالخرى ارسال گردد.

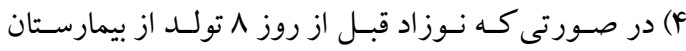
مرخص شود بايد به والدين در ارتباط با انجـام نمونسه گيـرى

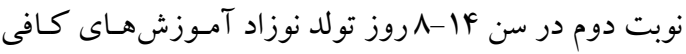
د اده شود. ه) در صورتى كه نوزاد در سن بيش از ه روز (تا دو ماهو هو روز از تولد)، در بيمارستان بسترى شده و غربالكرى نوزادان

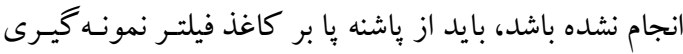
بهعمل آيد (حتى اكر آزمايشهاى تيروئيدى از طريق وريـد انجام شـوند) و بر اسـاس دسـتور العمل بـهـ آزما يشــاه ارسـال كردد. دستورالعمل غربالخرى نوزادان در موارد انتقال نوزاد بسـترى به بيمارستان ديخر 
برنامه مداخلهاى كشورى در حفظ ضريب هوشى كودكـان

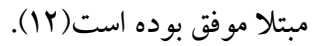

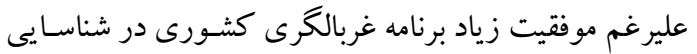

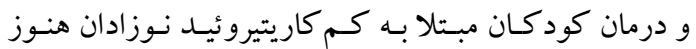
برخى جنبه هاى اصلى نظام مر اقبت اين بيمارى مورد ارزيابى دونى

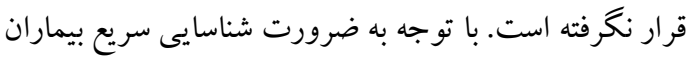
و اقدام بـه موقـع در شـروع درمـان بيمـارى، توجـه بـه زمـان

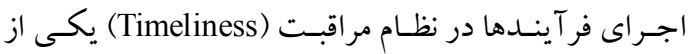
مهم ترينجنبه هاى نظام مر اقبت محسوب مى شى شود كـه نيازمنــ بررسى مىباشد (F)

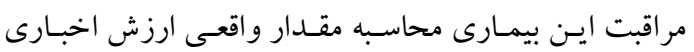
مثبـت تسـت اوليـه مـورد اسـتفاده بـراى غربـالكرى (TSH)

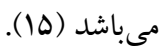
يكى از مهم ترينجالشهاى برنامه غربالخرى نوزادان در دنيـا، تعيين مقدار Cut off براى تستهاى غربالخرى مورد استفاده

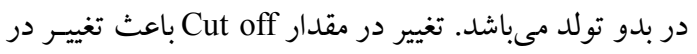

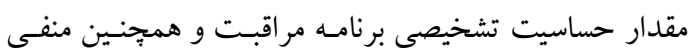

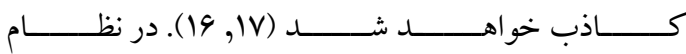
مراقبتكم كاريتيروئيدنوز ادان در اير ان، مقـدار Cut off اوليه

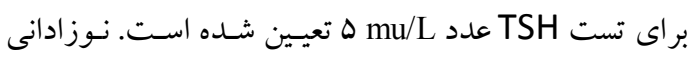
كه مقدار TSH اوليه آنها مساوى و بيشتر از

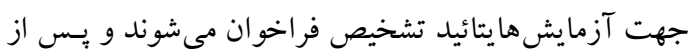

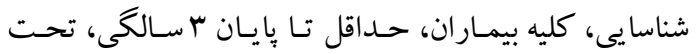

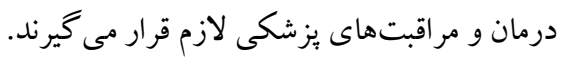

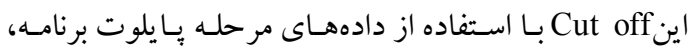

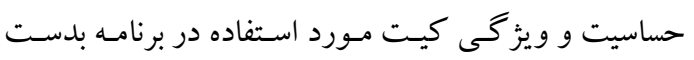

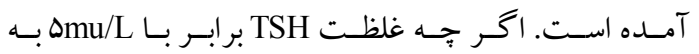
عنـوانCut off باعـث افزايش حساسـيت نظـام مراقبـت در شناسايى نوزادان مبتلا مى شود و تعداد زيادى بيمار شناسايى

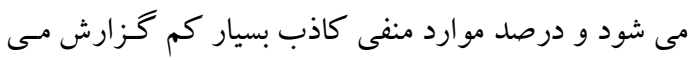
شود، اما تعيين درصد واقعى موارد منفى كاذب كشف درد نشده
آنهابين ه تـا 9/9 ميكرو گرم مسىباشـد. ايـن تصـميم بـراى

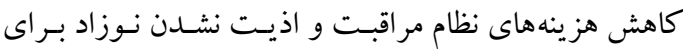

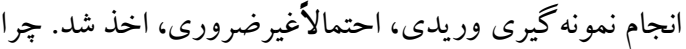
كه براساس شواهد إيدميولوزيك كشورى درصد زيـادى از

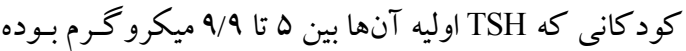

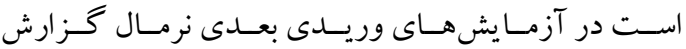
شدهاند. تغيير ديخر در نظام مراقبت اين بيمارى، طراحى يكك برنامه مشخص بر اى غربـالكرى كود كـان نـارس هسـت كـه شانس ابتلا به بيمارى در آنهابيش تر است. اين نوزادان در

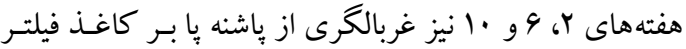
مىشوند. اين امر نيز موجب كاهش تعداد موارد منفى كاذب در جمعيت نوز ادان نارس مى شود.

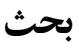
در مطالعه حاضر ساختار كلى نظـام مر اقبـت برنامـه كشـورى

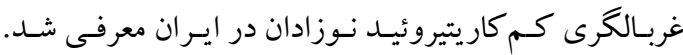
اجراى بايلوت برنامـه كثـورى غربـالخرى كـم كاريتيروئيـد نوزادان در ايران،درسال rیما هجرى شمسى انجـام شــه و

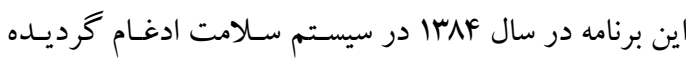

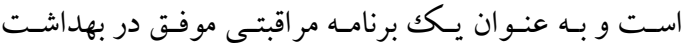

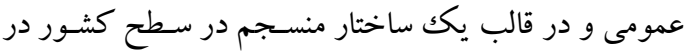
حال اجرا است. اين برنامه دستاوردهاى بسيار زيـادى داشـته

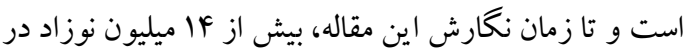

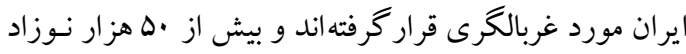

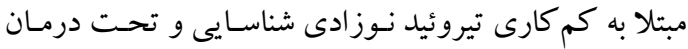

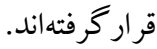
هدف اصلى نظام مر اقبت كم كاريتيروئيد نـوزادان در ايـران،

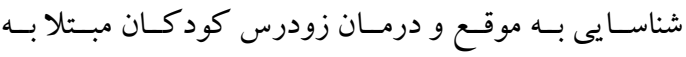

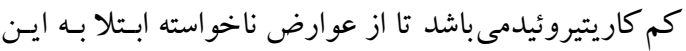

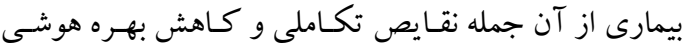

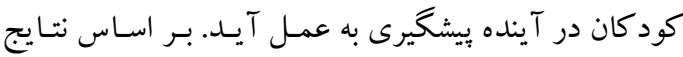

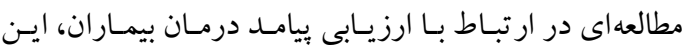

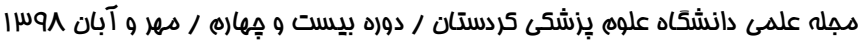




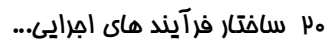

$$
\begin{aligned}
& \text { مدنظر سياستخذاران، محققان، مـديران، كارشناسـان و افراد }
\end{aligned}
$$

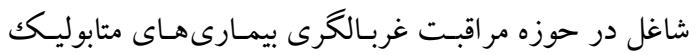

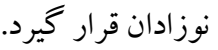

$$
\begin{aligned}
& \text { تشكر و قدردانى }
\end{aligned}
$$

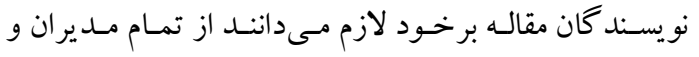

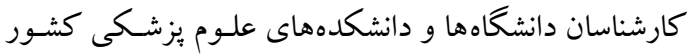

$$
\begin{aligned}
& \text { كه در اجر ایى برنامه كشورى غربـالكرى كـم كـارى تيروئيـد }
\end{aligned}
$$

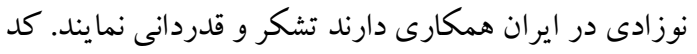

$$
\begin{aligned}
& \text { طرح: IR.MUK.REC.1397/294 }
\end{aligned}
$$$$
\text { از جالش هـاى برنامـه مسىباشـــ كـه نيازمنــد انجـام مطالعـات }
$$$$
\text { بيش ترمىباشد. }
$$

$$
\begin{aligned}
& \text { نتيجه كيرى }
\end{aligned}
$$

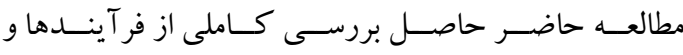

$$
\begin{aligned}
& \text { ساختارهاى نظام مر اقبت كشورى غربالخرى و مدير يتبيمارى } \\
& \text { كم كاريتيروئيد نوزادان در اير ان مى باشد. اين مطالعه عـلاوه } \\
& \text { بر اين كه جكيدهاى از اصول، كليات و نحوه اجر ایى مراقبت } \\
& \text { كم كاريتيروئيد نوزادان در ايـران را يـيش روى خوانيد آنسان }
\end{aligned}
$$

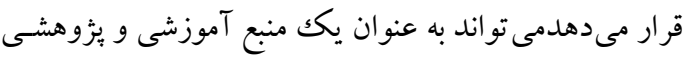

\section{References}

1. Gopalakrishnan V, Joshi K, Phadke S, Dabadghao P, Agarwal M, Das V, et al. Newborn screening for congenital hypothyroidism, galactosemia and biotinidase deficiency in Uttar Pradesh, India. Indian Pediatr 2014;51:701-5.

2. Léger J. Endocrinology and adolescence: congenital hypothyroidism: a clinical update of long-term outcome in young adults. Eur J Endocrinol 2015;172:R67-R77.

3. Behl T, Kaur I, Kaur C, Sihag S, Medapati S. Congenital hypothyroidism: An updated review of its pathogenesis. J Pharm Sci Rev Res. 2014;4:1-7.

4. Rovet J, Daneman D. Congenital hypothyroidism: a review of current diagnostic and treatment practices in relation to neuropsychologic outcome. Paediatr Drugs 2003;5:141-9.

5. Deladoëy J, Ruel J, Giguère Y, Van Vliet G. Is the incidence of congenital hypothyroidism really increasing? A 20-year retrospective population-based study in Quebec. J Clin Endocrinol Metab 2011;96:2422-9.

6. Mitchell ML, Hsu HW, Sahai I, Group MPEW. The increased incidence of congenital hypothyroidism: fact or fancy?. Clin Endocrinol 2011;75:806-10.

7. Olivieri A. Epidemiology of congenital hypothyroidism. Thyroid diseases in childhood: Springer; 2015: 53-63.

8. Mehran L, Khalili D, Yarahmadi S, Delshad H, Mehrabi Y, Amouzegar A, et al. Evaluation of the congenital hypothyroidism screening programme in Iran: a 3-year retrospective cohort study. Arch Dis Child Fetal Neonatal Ed 2019;104:F176-F81.

9. Bijarnia S, Wilcken B, Wiley VC. Newborn screening for congenital hypothyroidism in very-low-birth-weight babies: the need for a second test. J Inherit Metab Dis 2011;34:827-33.

10. Melmed S, Polonsky KS, Larsen PR, Kronenberg HM. Williams textbook of endocrinology. 13 nd ed. New York: Elsevier Health Sciences; 2011.

11. Yarahmadi SA, N. Newborn screening program on congenital hypothyroidism in I. R. Iran. Tehran: Ministry of Health and Medical Education; 2018.

12. Rahmani K, Yarahmadi S, Etemad K, Mehrabi Y, Aghang N, Koosha A, et al. Intelligence Quotient at the age of six years of iranian children with congenital hypothyroidism. Indian Pediatr 2018;55:121-4.

13. Jajosky RA, Groseclose SL. Evaluation of reporting timeliness of public health surveillance systems for infectious diseases. BMC Public Health 2004;4:29.

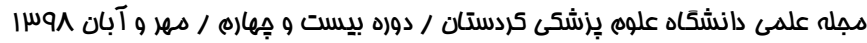


14. Huaman MA, Araujo-Castillo RV, Soto G, Neyra JM, Quispe JA, Fernandez MF, et al. Impact of two interventions on timeliness and data quality of an electronic disease surveillance system in a resource limited setting (Peru): a prospective evaluation. BMC Med Inform Decis Mak 2009;9:16.

15. German RR, Lee L, Horan J, Milstein R, Pertowski C, Waller M. Updated guidelines for evaluating public health surveillance systems. MMWR Recomm Rep 2001;50: quiz CE1-7.

16. Corbetta C, Weber G, Cortinovis F, Calebiro D, Passoni A, Vigone MC, et al. A 7 year experience with low blood TSH cutoff levels for neonatal screening reveals an unsuspected frequency of congenital hypothyroidism $(\mathrm{CH})$. Clin endocrinol 2009;71:739-45.

17. Mengreli C, Kanaka-Gantenbein C, Girginoudis P, Magiakou M-A, Christakopoulou I, Giannoulia-Karantana A, et al. Screening for congenital hypothyroidism: the significance of threshold limit in false-negative results. J Inherit Metab Dis 2010;95:4283-90.

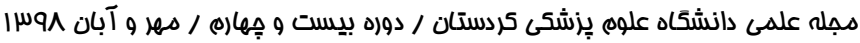

